Article

\title{
Cu Nanoparticles in Hydrogels of Chitosan-PVA Affects the Characteristics of Post-Harvest and Bioactive Compounds of Jalapeño Pepper
}

\author{
Zeus H. Pinedo-Guerrero ${ }^{1}$, Alma Delia Hernández-Fuentes ${ }^{2}$, Hortensia Ortega-Ortiz ${ }^{3}$, \\ Adalberto Benavides-Mendoza ${ }^{1}$, Gregorio Cadenas-Pliego ${ }^{3}$ and Antonio Juárez-Maldonado ${ }^{4, *}$ \\ 1 Departamento de Horticultura, Universidad Autónoma Agraria Antonio Narro, 25315 Saltillo, \\ Coahuila, Mexico; ing.zeuspinedo@gmail.com (Z.H.P.-G.); abenmen@gmail.com (A.B.-M.) \\ 2 Instituto de Ciencias Agropecuarias, Universidad Autónoma del Estado de Hidalgo, Tulancingo, \\ 43600 Hidalgo, Mexico; hfad@hotmail.com \\ 3 Centro de Investigación en Química Aplicada, 25294 Saltillo, Coahuila, Mexico; \\ hortensia.ortega@ciqa.edu.mx (H.O.-O.); gregorio.cadenas@ciqa.edu.mx (G.C.-P.) \\ 4 Departamento de Botánica, Universidad Autónoma Agraria Antonio Narro, 25315 Saltillo, Coahuila, Mexico \\ * Correspondence: juma841025@hotmail.com; Tel.: +52-844-411-0317
}

Academic Editor: Már Másson

Received: 31 March 2017; Accepted: 31 May 2017; Published: 2 June 2017

\begin{abstract}
Peppers are consumed all over the world due to the flavor, aroma, and color that they add to food. Additionally, they play a role in human health, as they contain a high concentration of bioactive compounds and antioxidants. The treatments used were an absolute control, Cs-PVA, and four treatments with $0.02,0.2,2$, and $10 \mathrm{mg}(\mathrm{nCu}) \mathrm{g}^{-1}$ (Cs-PVA). The application of $\mathrm{Cu}$ nanoparticles in chitosan-PVA hydrogels increases the content of capsaicin by up to $51 \%$ compared to the control. This application also increases the content of antioxidants ABTS [2,2'-azino-bis (3-ethylbenzothiazolin-6-sulfonic acid)] and DPPH (2,2-diphenyl-1-picrylhydrazyl), total phenols and flavonoids (4\%, $6.6 \%, 5.9 \%$, and $12.7 \%$, respectively) in jalapeño pepper fruits stored for 15 days at room temperature; under refrigeration, it increases DPPH antioxidants, total phenols, and flavonoids $(23.9 \%, 1.54 \%$, and $17.2 \%$, respectively). The application of $\mathrm{Cu}$ nanoparticles in chitosan-PVA hydrogels, even when applied to the substrate, not only has an effect on the development of the jalapeño pepper crop, but also modifies the post-harvest characteristics of the jalapeño pepper fruits.
\end{abstract}

Keywords: hydrogels of chitosan-PVA; bioactive compounds; capsaicin; antioxidants; jalapeño pepper; post-harvest.

\section{Introduction}

Mexico is the second greatest producer of fresh peppers worldwide, with an area of 149,000 hectares, and its main export destinations are the United States, Canada, and Spain, among others [1]. In Mexico, peppers are the eighth most economically valuable crop, with an average production volume of 2.2 million tons, of which approximately 900 thousand tons of fresh, dry, and processed peppers are exported [2]; in 2016, the production of peppers in its different varieties reached 2.3 million tons [1].

Peppers are consumed all over the world due to the flavor, aroma, and color that they add to food. In addition to their sensory importance, peppers play a role in human health, as they contain a high concentration of bio-functional compounds and antioxidants that are important in the prevention of cardiovascular diseases, cancer, and neurological disorders. The main compounds are capsaicin and dihydrocapsaicin; these compounds are synthesized in fruits [3], are responsible for the pungency, and represent $80-90 \%$ of the capsaicinoids of pepper species [4]. Excess reactive oxygen species (ROS) are 
associated with various diseases in humans and have led to an increased consumption in this type of food that reduces oxidative damage in biological systems [5].

Nanotechnology has led to great expectations for the development of new products and applications in a wide range of industrial and human consumption sectors. It is expected that this technology will revolutionize the entire food chain, ranging from production to processing and storage of vegetables and other products post-harvest [6]. However, the application of nanotechnology in plant sciences has received little interest compared to nanomedicine and nanopharmacology [7]. The application of nanoparticles (NPs) in different crop plants has been evaluated, and the effects of these vary greatly with plant species and other factors as dose and type of NPs [8]. The use of NPs as nanofertilizers is common as they enhance nutrient use efficiency and increase yields through optimized nutrient management [7]. However, the use of NPs as biostimulants of biocompounds in plant crops is little known. In this sense, it has been shown that $\mathrm{Cu}$ nanoparticles $(\mathrm{nCu})$ and their concentrations have a stimulatory effect that is related to the induction of antioxidant activity [9]. Also, the application of $\mathrm{nCu}$ in chitosan hydrogels was favorable to tomato growth and quality, increasing the catalase activity in the leaves and the lycopene content in the fruit [10]. Moreover, same authors found that application both $\mathrm{nCu}$ in chitosan hydrogels or only chitosan hydrogels decreased the concentration of $\mathrm{Cu}$ in plant tissue, additionally the fruit shows the lowest concentration of this mineral [10].

On the other hand, the management of such low concentrations may represent a problem when applied to plants, especially when nanoparticles are directed to the ground, because they can be inactivated or leached or because the amount is so small that it is difficult to handle. Chitosan has the ability to chelate minerals and other nutrients, making them more available to plants [11]. This is possible via the binding of metals through the functional groups (amino and hydroxyl) of chitosan [12]. Chitosan is a linear polymer formed by monomers of D-Glucosamine, a natural product derived mainly from the chitin of crustacean shells. Therefore, due to the characteristics of the bonding with chitosan-PVA metals, it can function as a vehicle for the application of NPs.

Although the effect of $\mathrm{nCu}$ is known for various crops [8], it is necessary to increase knowledge of fruit quality and post-harvest life. Thus, the objective of this work was to evaluate the effect of the application of $\mathrm{Cu}$ nanoparticles, introduced in chitosan-PVA hydrogels, on the growth of jalapeño pepper plants, the antioxidant content in fruits, and their post-harvest characteristics.

\section{Results and Discussion}

Morphology of nCu was analyzed using SEM and TEM is shown in Figure 1a,b respectively. The sphere morphology is shown clearly in these figures. Also, Figure 2a shows the diffraction patterns of $\mathrm{Cu}$ nanoparticles, in their initial state, without any treatment, three important peaks were detected, reflections corresponding to angle $2 \theta: 43.6^{\circ}, 50.8^{\circ}$, and $74.4^{\circ}$ corresponding to the crystalline planes (111), (200), and (220) associated with diffraction patterns of elemental copper. In the same figure, reflections are observed at the $2 \theta$ angles of $\mathrm{Cu}_{2} \mathrm{O}$ at 29.9, 37, 42.6, 62.4, and 74.4 corresponding to the crystalline planes (110), (111), (200), (220), and (311) according to the $\mathrm{Cu}_{2} \mathrm{O}$ diffraction patterns obtained from the equipment database. The Figure $2 \mathrm{~b}$ shows XRD pattern of the Cs-PVA hydrogel with $\mathrm{Cu}$ nanoparticles. This Figure shows a structure characterized by peaks at $2 \theta: 43.25^{\circ}(111), 50.34^{\circ}$ (200), and $74.04^{\circ}(220)$, which match exactly with the standard data of $\mathrm{Cu}$ crystals. Also, it is possible to observe additional peaks at $2 \theta$, that can be attributed to $\mathrm{Cu}_{2} \mathrm{O}, 37^{\circ}(110), 42.6^{\circ}(111), 62.4^{\circ}(200)$, and $74.4^{\circ}(220)$ and finally the peaks at $2 \theta$ between $10^{\circ}$ and $20^{\circ}$ are corresponding to amorphous polymer reflections. 

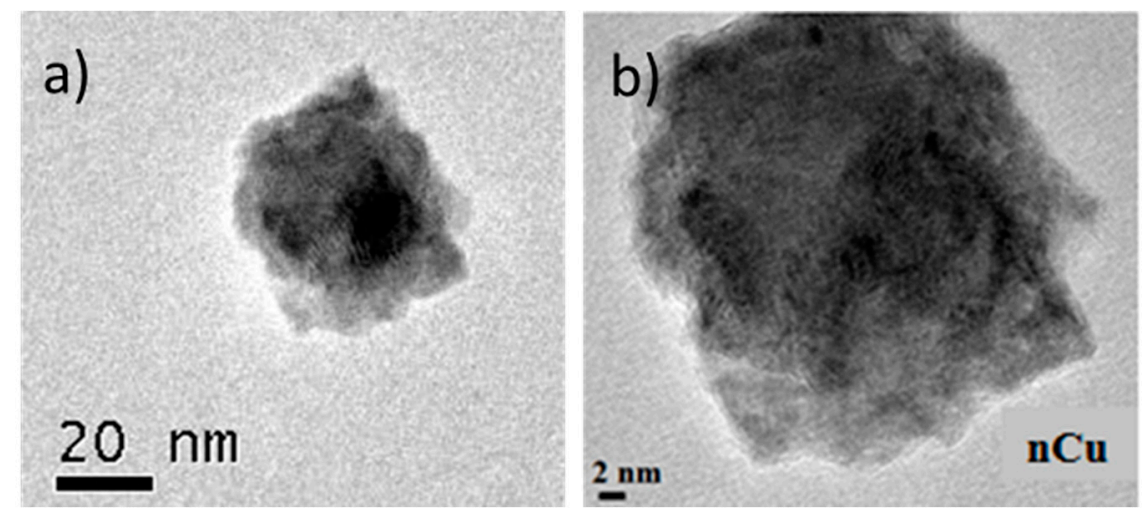

Figure 1. SEM (a) and TEM (b) images of nCu morphology.
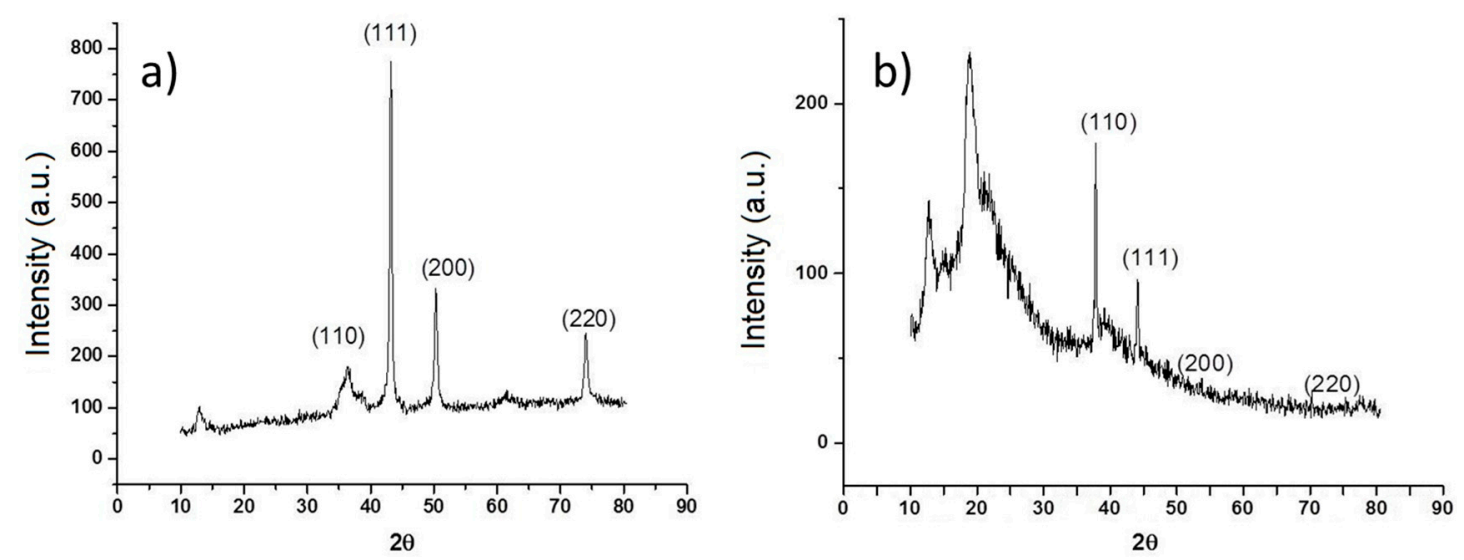

Figure 2. X-ray diffraction patterns of $\mathrm{nCu}(\mathbf{a})$ and $\mathrm{nCu}$ in hydrogels of chitosan-PVA (b).

The results of the growth and production variables of the jalapeño pepper plants are presented in Table 1. For the variable corresponding to the height of the plant, differences $(p \leq 0.05)$ were observed between the applied treatments. The highest height was observed in the absolute control, while the lowest height was observed in the Cs-PVA $+2.0 \mathrm{mg} \mathrm{nCu}$ treatment. Zuverza-Mena et al. [13] reported a decrease in growth in cilantro when applying $80 \mathrm{mg} \mathrm{nCu} \mathrm{kg}^{-1}$ to soil. Additionally, they mentioned that this reduction in growth does not seem to be associated with assimilation and transport. However, Rizwan et al. [8] concluded that NP toxicity can be manifested in the plant by mechanisms such as genotoxicity, alterations in nutrient absorption, and generation of ROS. This can result in decreased plant growth.

Differences in the number of fruits per plant $(p \leq 0.05)$ were observed; the highest number of fruits was present in the Cs-PVA $+0.2 \mathrm{mg} \mathrm{nCu}$ treatment, while the lowest number was observed in the Cs-PVA + $2.0 \mathrm{mg} \mathrm{nCu}$ treatment (Table 1). This result is similar to Juárez-Maldonado et al. [10], who found an increase in the number of tomato fruits treated with $0.006 \mathrm{mg} \cdot \mathrm{L}^{-1} \mathrm{nCu}+$ chitosan. Moreover, differences $(p \leq 0.05)$ were observed in the average weight and total weight of fruits. The highest total weight of harvested fruits was obtained with the Cs-PVA and Cs-PVA $+0.2 \mathrm{mg}$ $\mathrm{nCu}$ treatments, while the lowest total weight was observed for the Cs-PVA $+2.0 \mathrm{mg} \mathrm{nCu}$ treatment. For average fruit weight, the Cs-PVA treatment was best, and the lowest weight was observed in the Cs-PVA $+10 \mathrm{mg} \mathrm{nCu}$ treatment. This coincides with the results of a previous study [14] which demonstrates that exposure to NPs affects growth and development in several plant species. However, it differs from the report by Juárez-Maldonado et al. [10], who did not observe differences in the weight of tomato fruits treated with $\mathrm{nCu}+$ chitosan. It is common to observe this type of result with the application of nanoparticles in general, since both positive and negative effects on crop growth and 
yield have been reported [8]. For example, the application of nCuO reduces root development and outbreaks through the production of reactive oxygen species and lipid peroxidation. This is believed to occur through the interaction of NPs with proteins, membranes, nucleic acids, and metabolites, as well as free electrons on the surface of the NPs [15-17].

The dry and fresh weight of aerial biomass was not affected by the treatments since no differences were observed $(p \leq 0.05)$ (Table 1$)$. Juárez-Maldonado et al. [10] observed a similar response in fresh aerial weight, as no differences were found in tomato plants treated with chitosan and nCu. The chitosan alone had no effect; this result differs from that found by Benavides-Mendoza et al. [18] who reported an increase in biomass in lettuce plants treated with this compound. This indicates that the response to the application of chitosan or $\mathrm{nCu}$ is different for each plant species; the soil characteristics and microbial composition could also affect these responses. In addition, it is known that the application of NPs can produce positive or toxic effects depending on dose, form, size, or plant species [8].

Table 1. Plants of jalapeño peppers treated with Cs-PVA and different concentrations of nCu.

\begin{tabular}{ccccccc}
\hline Treatment & $\begin{array}{c}\text { Height } \\
(\mathbf{c m})\end{array}$ & $\begin{array}{c}\text { Number of } \\
\text { Fruits }\end{array}$ & $\begin{array}{c}\text { Average Fruits } \\
\text { Weight } \mathbf{( g )}\end{array}$ & $\begin{array}{c}\text { Total Fruits } \\
\text { Weight } \mathbf{( g )}\end{array}$ & $\begin{array}{c}\text { Fresh Weight } \\
\text { Aerial Biomass (g) }\end{array}$ & $\begin{array}{c}\text { Dry Weight Aerial } \\
\text { Biomass }(\mathbf{g})\end{array}$ \\
\hline Control & $115.7 \mathrm{a}$ & $115.8 \mathrm{ab}$ & $26.6 \mathrm{ab}$ & $3086.8 \mathrm{ab}$ & $808.6 \mathrm{a}$ & $192.9 \mathrm{a}$ \\
Cs-PVA & $110.6 \mathrm{ab}$ & $124.5 \mathrm{ab}$ & $27.0 \mathrm{a}$ & $3450.3 \mathrm{a}$ & $848.0 \mathrm{a}$ & $187.8 \mathrm{a}$ \\
Cs-PVA + $0.02 \mathrm{mg} \mathrm{nCu}$ & $114.3 \mathrm{ab}$ & $115.6 \mathrm{ab}$ & $26.2 \mathrm{ab}$ & $3028.7 \mathrm{ab}$ & $766.6 \mathrm{a}$ & $171.0 \mathrm{a}$ \\
Cs-PVA + 0.2 mg nCu & $113.5 \mathrm{ab}$ & $126.6 \mathrm{a}$ & $26.4 \mathrm{ab}$ & $3342.2 \mathrm{a}$ & $812.1 \mathrm{a}$ & $185.2 \mathrm{a}$ \\
Cs-PVA + $2.0 \mathrm{mg} \mathrm{nCu}$ & $109.1 \mathrm{~b}$ & $111.6 \mathrm{~b}$ & $26.9 \mathrm{ab}$ & $3002.04 \mathrm{~b}$ & $779.4 \mathrm{a}$ & $177.4 \mathrm{a}$ \\
Cs-PVA + $10 \mathrm{mg} \mathrm{nCu}$ & $112.3 \mathrm{ab}$ & $118.8 \mathrm{ab}$ & $25.3 \mathrm{~b}$ & $3005.6 \mathrm{ab}$ & $797.3 \mathrm{a}$ & $182.1 \mathrm{a}$ \\
CV $(\%)$ & 7.53 & 18.84 & 9.14 & 17.13 & 17.81 & 20.16 \\
\hline
\end{tabular}

Means with the same letters within the same column are statistically the same according to the Fisher Least Significant Difference test $(p \leq 0.05)$. CV (\%): Coefficient of variation. Each data is the average of 18 replicates.

Table 2 presents the results of the variable corresponding to weight loss. Differences $(p \leq 0.05)$ were observed at 15 and 30 days of storage both at room temperature and under refrigeration. There was less weight loss in the control (5.80\%) and the Cs-PVA $+2.0 \mathrm{mg} \mathrm{nCu}$ treatment $(6.02 \%)$ when the fruits were refrigerated for 15 days. However, after 30 days of storage under the same condition, the Cs-PVA $+10 \mathrm{mg} \mathrm{nCu}$ treatment showed the lowest weight loss (20.52\%).

For fruits stored for 15 days at room temperature, the lowest recorded loss was observed in the treatment of Cs-PVA $+0.2 \mathrm{mg} \mathrm{nCu}(11.74 \%)$. At 30 days storage, the lowest weight loss was observed in the Cs-PVA + $0.02 \mathrm{mg} \mathrm{nCu}$ treatment (19\%), and the highest weight loss was observed in the control fruits $(20.79 \%)$. This behavior can be due to lignification of cell wall, since NPs can be translocated to the fruits [19], and it has been demonstrated that application of $\mathrm{CuO}$ NPs produce this effect on plants [20-22]. When the cell wall is lignificated, the fruit lost less water, as a consequence the fruits of the control present more weight loss that $\mathrm{nCu}$ treatments.

The observed weight losses were higher than those reported by Hernández-Fuentes et al. [23] in bell pepper fruit var. California at 30 days storage under refrigeration conditions of $5 \pm 1{ }^{\circ} \mathrm{C}$ $(13.03 \%)$. However, this may be because of the lower storage temperature $\left(5^{\circ} \mathrm{C}\right)$ compared to this study. Báez-Sañudo et al. [24] reported that when fruits lose 6 to $7 \%$ of their weight, firmness and appearance decrease and consequently, quality declines. Espinosa-Torres et al. [25] found that for shelf conditions at 12 and $5{ }^{\circ} \mathrm{C}$ in Manzano pepper, the shelf life of fruits (one and two weeks, respectively) was prolonged. There was less weight loss and firmness in the fruits, without causing cold damage compared to ambient temperature $\left(20^{\circ} \mathrm{C}\right)$. This suggests that the shelf life of jalapeño peppers is approximately 15 days when stored under refrigeration $\left(10^{\circ} \mathrm{C}\right)$ and can be extended to lower temperatures, and values are lower when is maintained at room temperature. Therefore, the shelf life of jalapeño peppers can be extended with refrigeration due to decreasing metabolism as well as the degradation of polysaccharides [26]. 
Table 2. Weight loss during storage time in Cs-PVA-treated jalapeño peppers and different concentrations stored at room temperature $\left(20 \pm 1^{\circ} \mathrm{C}\right)$ and refrigeration $\left(10^{\circ} \mathrm{C}\right.$ and $80 \%$ Relative Humidity).

\begin{tabular}{ccccc}
\hline \multirow{2}{*}{ Treatment } & \multicolumn{2}{c}{ Refrigerated } & \multicolumn{2}{c}{ Room Temperature } \\
\cline { 2 - 5 } & 15 Days & 30 Days & 15 Days & 30 Days \\
\hline Control & $5.80 \mathrm{c}$ & $23.06 \mathrm{a}$ & $12.66 \mathrm{ab}$ & $20.79 \mathrm{a}$ \\
Cs-PVA & $7.91 \mathrm{a}$ & $22.32 \mathrm{ab}$ & $13.76 \mathrm{a}$ & $20.15 \mathrm{ab}$ \\
Cs-PVA + 0.02 mg nCu & $7.84 \mathrm{ab}$ & $22.27 \mathrm{ab}$ & $12.80 \mathrm{ab}$ & $19.00 \mathrm{~b}$ \\
Cs-PVA + 0.2 mg nCu & $7.30 \mathrm{abc}$ & $21.93 \mathrm{ab}$ & $11.74 \mathrm{~b}$ & $20.53 \mathrm{a}$ \\
Cs-PVA + 2.0 mg nCu & $6.02 \mathrm{c}$ & $23.82 \mathrm{a}$ & $12.48 \mathrm{ab}$ & $20.31 \mathrm{a}$ \\
Cs-PVA + 10 mg nCu & $6.28 \mathrm{bc}$ & $20.52 \mathrm{~b}$ & $13.31 \mathrm{a}$ & $20.26 \mathrm{ab}$ \\
CV (\%) & 19.40 & 7.62 & 10.27 & 5.45 \\
\hline
\end{tabular}

Means with the same letters within the same column are statistically the same according to the Fisher Least Significant Difference test $(p \leq 0.05)$. CV $(\%)$ : Coefficient of variation. Each data is the average of six replicates.

The results of the total soluble solids (TSS) content are presented in Table 3. Differences $(p \leq 0.05)$ were observed at 0 and 15 days of storage at room temperature. The treatment of Cs-PVA $+2.0 \mathrm{mg} \mathrm{nCu}$ presented the highest TSS content, both at 0 days and at 15 days of storage, with values of 4.80 and $6.37^{\circ}$ Brix, respectively. In addition, a trend of increased TSS at up to 15 days of storage was generally observed. When fruits were refrigerated, differences $(p \leq 0.05)$ were observed at 0,15 , and 30 days of storage. In this case, unlike for fruits stored at room temperature, the TSS content remained more even. It was observed that the treatment of Cs-PVA $+2.0 \mathrm{mg} \mathrm{nCu}$ presented the highest values of TSS, especially at 30 days of storage $\left(5.67^{\circ}\right.$ Brix). However, there were differences between the values observed under refrigeration in the Cs-PVA $+2.0 \mathrm{mg} \mathrm{nCu}$ treatment compared to those obtained at room temperature, since in the latter condition there was $12 \%$ more TSS.

In general, an increase in the concentration of TSS was observed with the application of $\mathrm{Cs}-\mathrm{PVA}+\mathrm{nCu}$; values up to $6.37^{\circ} \mathrm{Brix}(\mathrm{Cs}-\mathrm{PVA}+2.0 \mathrm{mg} \mathrm{nCu})$ were obtained, exceeding those reported by Hernández-Fuentes et al. [23] in bell pepper fruits var. California stored under refrigeration at $5 \pm 1{ }^{\circ} \mathrm{C}$ for 30 days $\left(4.96^{\circ} \mathrm{Brix}\right)$. This tendency to increase occurs because TSS increases as fruit matures, due to the degradation and biosynthesis of polysaccharides and the accumulation of simple sugars [26]. In addition, the accumulation of sugars in non-climacteric fruits is associated with the development of optimal quality for consumption [27]. Therefore, a higher accumulation of TSS represents higher quality fruit, as observed in this experiment when applying the Cs-PVA $+\mathrm{nCu}$ treatment. When the fruits are refrigerated, their metabolism decreases so the increase in TSS is not limited. In contrast to what was observed in this study, Juárez-Maldonado et al. [10] observed no difference in TSS in tomato fruits with the application of $\mathrm{nCu}$ or $\mathrm{nCu}+$ chitosan, indicating that the effect of the application of these types of compounds may be different for each vegetable.

Table 3. Behavior of total soluble solids ( ${ }^{\circ}$ Brix) during storage time in jalapeño pepper fruits treated with Cs-PVA and different concentrations of $\mathrm{nCu}$ stored at room temperature $\left(20 \pm 1^{\circ} \mathrm{C}\right)$ and refrigeration $\left(10^{\circ} \mathrm{C}\right.$ And $80 \%$ Relative Humidity).

\begin{tabular}{lllllll}
\hline \multirow{2}{*}{ Treatment } & \multicolumn{3}{c}{ Room Temperature } & \multicolumn{3}{c}{ Refrigerated } \\
\cline { 2 - 7 } & Initial & 15 Days & 30 Days & Initial & 15 Days & 30 Days \\
\hline Control & $4.47 \mathrm{ab}$ & $4.50 \mathrm{~cd}$ & $5.30 \mathrm{a}$ & $4.47 \mathrm{ab}$ & $4.53 \mathrm{a}$ & $5.20 \mathrm{ab}$ \\
Cs-PVA & $4.33 \mathrm{ab}$ & $4.70 \mathrm{~cd}$ & $5.17 \mathrm{a}$ & $4.33 \mathrm{ab}$ & $4.13 \mathrm{~b}$ & $4.77 \mathrm{bc}$ \\
Cs-PVA + 0.02 mg nCu & $4.17 \mathrm{~b}$ & $5.23 \mathrm{~b}$ & $5.20 \mathrm{a}$ & $4.17 \mathrm{~b}$ & $4.57 \mathrm{a}$ & $4.43 \mathrm{~cd}$ \\
Cs-PVA + 0.2 mg nCu & $4.47 \mathrm{ab}$ & $4.37 \mathrm{~d}$ & $5.50 \mathrm{a}$ & $4.47 \mathrm{ab}$ & $4.60 \mathrm{a}$ & $4.27 \mathrm{~d}$ \\
Cs-PVA + 2.0 mg nCu & $4.80 \mathrm{a}$ & $6.37 \mathrm{a}$ & $4.83 \mathrm{a}$ & $4.80 \mathrm{a}$ & $4.47 \mathrm{a}$ & $5.67 \mathrm{a}$ \\
Cs-PVA + 10 mg nCu & $4.67 \mathrm{ab}$ & $4.80 \mathrm{c}$ & $4.67 \mathrm{a}$ & $4.67 \mathrm{ab}$ & $3.63 \mathrm{c}$ & $4.10 \mathrm{~d}$ \\
CV $(\%)$ & 6.48 & 4.33 & 9.75 & 6.48 & 3.49 & 5.61 \\
\hline
\end{tabular}

Values with the same letters within the same column are statistically the same according to the Fisher Least Significant Difference test $(p \leq 0.05)$. CV $(\%)$ : Coefficient of variation. Each data is the average of six replicates. 
For titratable acidity (TA), differences $(p \leq 0.05)$ were observed for almost all storage times under both room temperature and refrigeration. The results are presented in Table 4 . In fruits stored at room temperature, a clear increasing tendency was observed as storage time passed in all treatments, including the control. In the case of fruits stored under refrigeration, this increasing tendency was observed only in the control. It has been reported that TA from different pepper cultivars increases with maturation. As the fruit matures, metabolic reactions increase the concentration of organic acids involved in the Krebs cycle [26]. Metabolism is reduced under refrigeration, resulting in lower TA content in the refrigerated fruits.

At the initial storage time, the treatment consisting of Cs-PVA $+2.0 \mathrm{mg} \mathrm{nCu}$ showed the highest value of titratable acidity in the fruits $(0.65 \%)$. However, at 30 days of storage at ambient temperature, the Cs-PVA treatment exhibited the highest value $(1.48 \% \mathrm{TA})$. In the case of refrigerated fruits at 30 days of storage, the control had the highest value $(1.13 \% \mathrm{TA})$, surpassing the rest of the treatments. These acids serve as the energy reserve and participate in metabolic reactions for the synthesis of pigments, enzymes, and other materials and the degradation of pectins and celluloses that are essential for maturation processes [26]. The titratable acidity is therefore expected to increase with storage time.

Juárez-Maldonado et al. [10] reported values of $0.38 \%$ and $0.45 \%$ TA for tomato fruits treated with $\mathrm{nCu}+$ chitosan and chitosan, respectively. In the case of chitosan, the values were identical to those found here in jalapeño pepper $(0.45 \%)$, whereas with the application of $\mathrm{nCu}$, higher values were observed in jalapeño pepper compared to tomato. In addition, these authors reported an increase in the titratable acidity of tomato fruits treated with chitosan alone. This differs from what was found in the jalapeño pepper fruits in this study, since there were no differences between the control and the application of chitosan alone. Additionally, in the case of jalapeño peppers, the application of 0.2 and $2.0 \mathrm{mg} \mathrm{nCu}+\mathrm{Cs}-\mathrm{PVA}$ had a positive effect on the increase of TA. This suggests that both chitosan and $\mathrm{nCu}+\mathrm{Cs}-\mathrm{PVA}$ directly influence the behavior of this variable with storage time in pepper fruits.

Table 4. Behavior of titratable acidity (\% citric acid) during storage time in jalapeño pepper fruits treated with Cs-PVA and different concentrations of $\mathrm{nCu}$ stored at room temperature $\left(20 \pm 1^{\circ} \mathrm{C}\right)$ and refrigeration $\left(10{ }^{\circ} \mathrm{C}\right.$ and $80 \%$ Relative Humidity).

\begin{tabular}{lllllll}
\hline \multirow{2}{*}{ Treatment } & \multicolumn{3}{c}{ Room Temperature } & \multicolumn{3}{c}{ Refrigerated } \\
& Initial & 15 Days & 30 Days & Initial & 15 Days & 30 Days \\
\hline Control & $0.48 \mathrm{ab}$ & $0.61 \mathrm{a}$ & $1.24 \mathrm{abc}$ & $0.37 \mathrm{~b}$ & $0.60 \mathrm{a}$ & $1.13 \mathrm{a}$ \\
Cs-PVA & $0.45 \mathrm{ab}$ & $0.85 \mathrm{a}$ & $1.48 \mathrm{a}$ & $0.45 \mathrm{ab}$ & $0.35 \mathrm{~b}$ & $0.76 \mathrm{~b}$ \\
Cs-PVA + 0.02 mg nCu & $0.35 \mathrm{~b}$ & $0.72 \mathrm{a}$ & $1.01 \mathrm{c}$ & $0.35 \mathrm{~b}$ & $0.61 \mathrm{a}$ & $0.74 \mathrm{~b}$ \\
Cs-PVA + 0.2 mg nCu & $0.60 \mathrm{ab}$ & $0.73 \mathrm{a}$ & $1.36 \mathrm{ab}$ & $0.60 \mathrm{a}$ & $0.55 \mathrm{ab}$ & $0.87 \mathrm{~b}$ \\
Cs-PVA + 2.0 mg nCu & $0.65 \mathrm{a}$ & $0.82 \mathrm{a}$ & $1.08 \mathrm{c}$ & $0.65 \mathrm{a}$ & $0.37 \mathrm{~b}$ & $0.87 \mathrm{~b}$ \\
Cs-PVA + 10 mg nCu & $0.37 \mathrm{~b}$ & $0.74 \mathrm{a}$ & $1.11 \mathrm{bc}$ & $0.37 \mathrm{~b}$ & $0.55 \mathrm{ab}$ & $0.74 \mathrm{~b}$ \\
CV $(\%)$ & 24.63 & 19.76 & 12.56 & 5.61 & 25.05 & 23.92 \\
\hline
\end{tabular}

Values with the same letters within the same column are statistically the same according to the Fisher Least Significant Difference test $(p \leq 0.05)$. CV $(\%)$ : Coefficient of variation. Each datum is the average of six replicates.

The results regarding $\mathrm{pH}$ are presented in Table 5. At the initial evaluation time point, no differences $(p \leq 0.05)$ were observed between treatments, indicating that the application of Cs-PVA alone or with $\mathrm{nCu}$ does not affect this variable. However, at 15 days storage at both room temperature and refrigeration, the $\mathrm{pH}$ of all treatments was found to be statistically lower compared to the control. This differs from the report by Juárez-Maldonado et al. [10], since they recorded a pH increase in tomato fruits treated with chitosan $+\mathrm{nCu}$, indicating that the effect may be different for each vegetable to which it is applied. At 30 days storage at room temperature, it was observed that treatment with Cs-PVA +0.2 $\mathrm{mg} \mathrm{nCu}$ had the lowest $\mathrm{pH}$ value (4.57), significantly different from the rest of the treatments. It was the only treatment in which $\mathrm{pH}$ decreased as storage time increased. In the case of 30 days of refrigeration, there was no significant difference between treatments. Hernández-Fuentes et al. [23] reported on bell pepper fruits var. California stored under refrigeration at $5 \pm 1{ }^{\circ} \mathrm{C}$; the $\mathrm{pH}$ values ranged from 5.98 to 
6.08 at 0 and 30 days of storage, respectively, slightly higher than observed in this study. Tucker [28] reported that the $\mathrm{pH}$ in several fruits behaved inversely to variation in titratable acidity, whereas Hernández-Fuentes et al. [23] reported a similar tendency in bell pepper fruits, which coincides perfectly with that observed in the control jalapeño pepper fruits (Tables 4 and 5). In treatments with Cs-PVA alone and with $\mathrm{nCu}$, this trend is not observed, indicating that their application modifies $\mathrm{pH}$ behavior.

Table 5. pH behavior during storage time in pepper fruits treated with Cs-PVA and different concentrations of $\mathrm{nCu}$ stored at room temperature $\left(20 \pm 1{ }^{\circ} \mathrm{C}\right)$ and refrigeration $\left(10{ }^{\circ} \mathrm{C}\right.$ and $80 \%$ Relative Humidity).

\begin{tabular}{lllllll}
\hline \multirow{2}{*}{ Treatment } & \multicolumn{3}{c}{ Room Temperature } & \multicolumn{3}{c}{ Refrigerated } \\
\cline { 2 - 7 } & Initial & 15 Days & 30 Days & Initial & 15 Days & 30 Days \\
\hline Control & $5.72 \mathrm{a}$ & $5.49 \mathrm{a}$ & $5.22 \mathrm{a}$ & $5.72 \mathrm{a}$ & $5.51 \mathrm{a}$ & $5.21 \mathrm{a}$ \\
Cs-PVA & $5.53 \mathrm{a}$ & $5.15 \mathrm{~b}$ & $5.45 \mathrm{a}$ & $5.53 \mathrm{a}$ & $5.31 \mathrm{~b}$ & $5.23 \mathrm{a}$ \\
Cs-PVA + 0.02 mg nCu & $5.50 \mathrm{a}$ & $5.08 \mathrm{bc}$ & $5.67 \mathrm{a}$ & $5.50 \mathrm{a}$ & $5.26 \mathrm{~b}$ & $5.32 \mathrm{a}$ \\
Cs-PVA + 0.2 mg nCu & $5.72 \mathrm{a}$ & $5.16 \mathrm{~b}$ & $4.57 \mathrm{~b}$ & $5.72 \mathrm{a}$ & $5.21 \mathrm{~b}$ & $5.32 \mathrm{a}$ \\
Cs-PVA + 2.0 mg nCu & $5.70 \mathrm{a}$ & $5.08 \mathrm{c}$ & $5.35 \mathrm{a}$ & $5.70 \mathrm{a}$ & $5.20 \mathrm{~b}$ & $5.19 \mathrm{a}$ \\
Cs-PVA + 10 mg nCu & $5.88 \mathrm{a}$ & $5.17 \mathrm{~b}$ & $5.46 \mathrm{a}$ & $5.88 \mathrm{a}$ & $5.26 \mathrm{~b}$ & $5.30 \mathrm{a}$ \\
CV (\%) & 4.52 & 1.23 & 4.77 & 4.52 & 1.62 & 1.52 \\
\hline
\end{tabular}

Values with the same letters within the same column are statistically the same according to the Fisher Least Significant Difference test $(p \leq 0.05)$. CV (\%): Coefficient of variation. Each data is the average of six replicates.

Figure 3 shows the results of capsaicin content in jalapeno pepper fruits, where statistical differences between treatments were observed $(p \leq 0.05)$. It was observed that the Cs-PVA had no effect on this variable, since it presented values equal to the control. In contrast, the treatment of Cs-PVA $+10 \mathrm{mg} \mathrm{nCu}$ generated the highest concentration of capsaicin, exceeding the control by $51 \%$. Additionally, the treatment of Cs-PVA $+2 \mathrm{mg} \mathrm{nCu}$ was greater than the control by $29 \%$. In general, a clear trend of capsaicin increase was observed as $\mathrm{nCu}$ increased (Figure 3).

Capsaicin is one of the main antioxidants of jalapeno pepper [4] and protects cells from ROS. Therefore, it is possible that the observed increase in this compound is due to the induction of the antioxidant activity by the $\mathrm{nCu}$ [9], since these nanoparticles can interact with the intracellular structures [29], stimulating the formation of ROS. Ultimately, the plant defense system generates enzymatic and non-enzymatic antioxidant compounds [8], resulting in the accumulation of observed capsaicin (Figure 3).

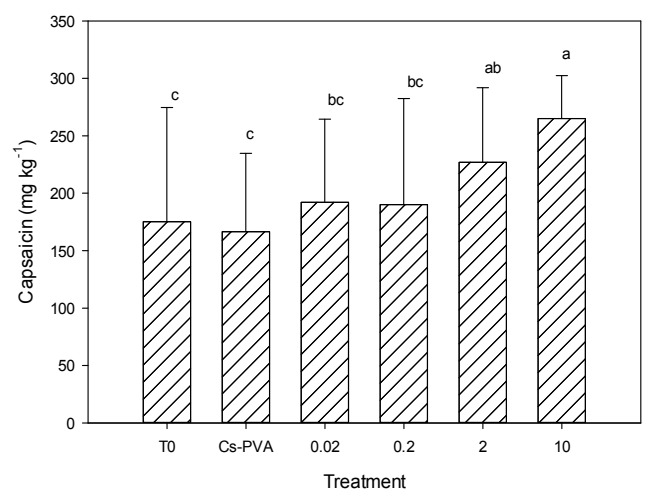

Figure 3. Capsaicin content in jalapeño pepper fruits. T0: Control; Cs-PVA: Only Chiosan-PVA; 0.02: Cs-PVA + $0.02 \mathrm{mg} \mathrm{nCu}$; 0.2: Cs-PVA + $0.2 \mathrm{mg} \mathrm{nCu}$; 2: Cs-PVA + $2.0 \mathrm{mg} \mathrm{nCu} ; 10:$ Cs-PVA + $10 \mathrm{mg}$ $\mathrm{nCu}$. Means with the same letters within the same column are statistically the same according to the Fisher Least Significant Difference test $(p \leq 0.05)$. Bars represent standard deviation. Each datum is the average of five replicates. 
The results of antioxidant capacity, total phenols and flavonoids are presented in Table 6 . There are significant differences between treatments $(p \leq 0.05)$ in all variables, regardless of whether the pepper fruits were stored at room temperature or under refrigeration.

Table 6. Antioxidant capacity by ABTS [2,2'-azino-bis (3-ethylbenzothiazolin-6-sulfonic acid)] and $\mathrm{DPPH}(2,2-$ diphenyl-1-picrylhydrazyl), Total phenols and flavonoids in jalapeño pepper fruits treated with Cs-PVA and different concentrations of $\mathrm{nCu}$ stored at room temperature $\left(20 \pm 1{ }^{\circ} \mathrm{C}\right)$ and refrigeration $\left(10{ }^{\circ} \mathrm{C}\right.$ and $80 \%$ Relative Humidity) for 15 days.

\begin{tabular}{|c|c|c|c|c|c|c|c|c|}
\hline Treatment & \multicolumn{4}{|c|}{ Room temperature } & \multicolumn{4}{|c|}{ Refrigerated } \\
\hline Control & $117.10 \mathrm{bc}$ & $107.27 \mathrm{c}$ & $61.07 \mathrm{~b}$ & $245.92 \mathrm{~d}$ & $120.22 \mathrm{a}$ & $87.68 \mathrm{~d}$ & $62.22 \mathrm{~b}$ & $292.85 c$ \\
\hline Cs-PVA + $0.02 \mathrm{mg} \mathrm{nCu}$ & $121.79 \mathrm{a}$ & $78.03 \mathrm{e}$ & $54.29 c$ & $277.20 \mathrm{a}$ & $102.27 \mathrm{c}$ & $108.69 \mathrm{a}$ & $56.44 \mathrm{~d}$ & $343.23 \mathrm{a}$ \\
\hline Cs-PVA + $0.2 \mathrm{mg} \mathrm{nCu}$ & $118.93 \mathrm{~b}$ & $94.34 \mathrm{~d}$ & $61.67 \mathrm{~b}$ & $270.80 \mathrm{~b}$ & $104.72 \mathrm{bc}$ & 82.93 e & $63.18 \mathrm{a}$ & $262.59 \mathrm{e}$ \\
\hline $\mathrm{CV}(\%)$ & 1.25 & 1.25 & 1.32 & 0.66 & 2.19 & 1.63 & 1.01 & 0.55 \\
\hline
\end{tabular}

ABTS (mg Ascorbic Acid Equivalents $100 \mathrm{~g}^{-1}$ Dry Weight); DPPH (mg Ascorbic Acid Equivalents $100 \mathrm{~g}^{-1}$ Dry Weight); TP: Total phenols (mg Galic Acid Equivalents $100 \mathrm{~g}^{-1}$ Dry Weight); Fl: Flavonoids (mg Equivalents of Quercetin $100 \mathrm{~g}^{-1}$ Dry Weight). Values with the same letters within the same column are statistically the same according to the Fisher Least Significant Difference test $(p \leq 0.05)$. CV $(\%)$ : Coefficient of variation. Each data is the average of three replicates.

The antioxidant capacity of ABTS [2,2'-azino-bis (3-ethylbenzothiazolin-6-sulfonic acid)] in the fruits stored at room temperature was higher in the Cs-PVA $+0.02 \mathrm{mg} \mathrm{nCu}$ treatment $[121.79 \mathrm{mg}$ ascorbic acid equivalents (AAE) $100 \mathrm{~g}^{-1}$ Dry Weight (DW)] and 4\% more than the control, while in the refrigerated fruits, the highest content was present in the control (120.22 mg AAE $\left.100 \mathrm{~g}^{-1} \mathrm{DW}\right)$.

The antioxidant capacity of DPPH (2,2-diphenyl-1-picrylhydrazyl) in fruits stored at room temperature was higher in the Cs-PVA $+10 \mathrm{mg} \mathrm{nCu}$ treatment $\left(114.35 \mathrm{mg}\right.$ AAE $\left.100 \mathrm{~g}^{-1} \mathrm{DW}\right)$, followed by Cs-PVA $+2.0 \mathrm{mg} \mathrm{nCu}\left(109.90 \mathrm{mg} \mathrm{AAE} 100 \mathrm{~g}^{-1} \mathrm{DW}\right)$, which were both higher than the control by $6.6 \%$ and $2.5 \%$, respectively. In the refrigerated fruits, the highest value was obtained with Cs-PVA $+0.2 \mathrm{mg}$ $\mathrm{nCu}\left(108.69 \mathrm{mg}\right.$ AAE $\left.100 \mathrm{~g}^{-1} \mathrm{DW}\right)$ followed by Cs-PVA + $10 \mathrm{mg} \mathrm{nCu}\left(103.74 \mathrm{mg}\right.$ AAE $\left.100 \mathrm{~g}^{-1} \mathrm{DW}\right)$. Both treatments were higher than the control by $23 \%$ and $18 \%$, respectively, and lower than those obtained by Kim et al. [30] in the Capsicum annum Da-Bok cultivar (280.5 mg AAE $100 \mathrm{~g}^{-1}$ DW).

It is believed that the stimulatory effects of $\mathrm{nCu}$ are related to the induction of antioxidant activity [9], since they can interact with intracellular structures [29] by stimulating the formation of ROS, which in turn activates the antioxidant defense system of plants. This is possible since nanoparticles can cross cell walls [29] by several ways: endocytosis, pore formation, carrier proteins, or through plasmodesmata [19]. Even if there are the ion channels, they have size around $1 \mathrm{~nm}$, thus nanoparticles are unlikely to cross the cell wall effectively [19]. The defense system of plants combines the generation of enzymatic and non-enzymatic antioxidant compounds [8], which can ultimately result in an increase of this type of compounds, as observed clearly in capsaicin content (Figure 3), and some treatments related to total phenols and flavonoids in both room temperature and refrigeration of this study (Table 6). The changes of enzymatic antioxidants have been demonstrated by Juárez-Maldonado et al. [10] in tomato plants treated with $\mathrm{nCu}+$ chitosan, where the catalase activity was more than five times higher than the control. This positive effect can be observed under light stress conditions by NPs, but can change under conditions of high stress where the activity of the antioxidant enzymes decreases due to the oxidative explosion [8]. Thus, it is possible to find different effects on antioxidant capacity depending on the dose of NPs used, as observed in the results of the present study (Table 6).

Total phenol content differences $(p \leq 0.05)$ were observed in fruits stored at both room temperature and under refrigeration. When the fruits were stored at room temperature, the Cs-PVA $+2.0 \mathrm{mg}$ $\mathrm{nCu}$ treatment generated the highest value [64.71 mg galic acid equivalents (GAE) $100 \mathrm{~g}-1 \mathrm{DW}$ ], 
at $5.9 \%$ more than the control. On the other hand, in refrigerated fruits, the highest content was observed in the Cs-PVA + $0.2 \mathrm{mg} \mathrm{nCu}\left(63.18 \mathrm{mg}\right.$ GAE $\left.100 \mathrm{~g}^{-1} \mathrm{DW}\right)$ treatment, at $1.5 \%$ higher than the control. The values in both cases are much lower than those reported by Vega-Gálvez et al. [31] for Capsicum annuum L. var. Hungarian (1359 mg GAE $100 \mathrm{~g}^{-1} \mathrm{DW}$ ). However, in comparison to values reported by Juárez-Maldonado et al. [10] in tomato fruits treated with $\mathrm{nCu}+$ chitosan (5.8 mg GAE $100 \mathrm{~g}^{-1} \mathrm{DW}$ ), the values observed in jalapeño pepper were higher (approximately 11-fold). Ghasemnezhad et al. [26] reported $120 \mathrm{mg}$ GAE $100 \mathrm{~g}^{-1} \mathrm{DW}$ for the Capsicum annuum genotype Fox and $95 \mathrm{mg}$ GAE $100 \mathrm{~g}^{-1}$ DW for the Arian genotype, higher than those found in the present study. Deepa et al. [32] also reported higher values for the pepper genotype Tanvi $186 \mathrm{mg}$ GAE $100 \mathrm{~g}^{-1} \mathrm{DW}$ and the genotype Flamingo $1122 \mathrm{mg} 100 \mathrm{~g}^{-1} \mathrm{DW}$, as did Lee et al. [33] in the jalapeño var. Mitla (179.1 mg GAE $\left.100 \mathrm{~g}^{-1} \mathrm{DW}\right)$.

Flavonoids content differed $(p \leq 0.05)$ between fruits stored under ambient temperature and in refrigeration. In both cases, the best treatment was Cs-PVA $+0.02 \mathrm{mg} \mathrm{nCu}$, surpassing the control by $13 \%$ and $17 \%$, respectively. The observed response may be due to an induction effect of the antioxidant activity of $\mathrm{nCu}$ at low concentrations [9]. It was also observed that the highest flavonoid content was obtained for refrigerated fruits in almost all treatments. This is explained by the fact that the total flavonoid content decreases during maturation [34]. When the fruits are refrigerated, the maturation-related decrease is delayed so that the flavonoid content is maintained compared to fruits stored at room temperature. The highest flavonoid content was $277.29 \mathrm{mg}$ equivalent of quercetin (EQ) $100 \mathrm{~g}^{-1} \mathrm{DW}$, in the Cs-PVA $+0.02 \mathrm{mg} \mathrm{nCu}$ treatment under ambient temperature conditions; this condition exhibited a content $10 \%$ higher than the control. Under refrigeration, $343.26 \mathrm{mg}$ EQ $100 \mathrm{~g} \mathrm{~g}^{-1}$ DW was observed with the same treatment, surpassing the control by $17 \%$. These values are much higher than those reported by Ghasemnezhad et al. [26] in the Capsicum annuum genotypes Zorro (11.7 mg EQ $\left.100 \mathrm{~g}^{-1} \mathrm{DW}\right)$ and Arian (4.2 mg EQ $\left.100 \mathrm{~g}^{-1} \mathrm{DW}\right)$; Lee et al. [33] reported a lower value for the jalapeño var. Mitla (5.32 $\mathrm{mg}$ EQ $\left.100 \mathrm{~g}^{-1} \mathrm{DW}\right)$.

\section{Materials and Methods}

\subsection{Synthesis of Chitosan-Polyzinyl Alcohol (Cs-PVA) Hydrogels and Absorption of Cu Nanoparticles in Hydrogels}

The synthesis of Cs-PVA hydrogels was performed in the pilot plant of the Applied Chemistry Research Center (CIQA). First, $250 \mathrm{~mL}$ of $2 \%$ chitosan (Marine Chemical and Mv =200,000 g/mol) and $250 \mathrm{~mL}$ of $4 \%$ polyvinyl alcohol (PVA) (Aldrich, St. Louis, MO, USA, Mw = 30,000 to 50,000 and $98 \%$ hydrolysis) were dissolved by mixing for two hours at $300 \mathrm{rpm}$ and $60^{\circ} \mathrm{C}$ to obtain a hydrogel in a 1:2 ratio (Cs: PVA). Subsequently, $2.27 \mathrm{~mL}$ of the crosslinker (50\% glutaraldehyde) was added at $450 \mathrm{rpm}$ for $5 \mathrm{~min}$ at $25^{\circ} \mathrm{C}$. Then, $100 \mathrm{~mL}$ of $6 \% \mathrm{NaOH}$ was added at $300 \mathrm{rpm}$ and $25^{\circ} \mathrm{C}$ for one hour. Finally, the Cs-PVA hydrogels were washed and purified with distilled water and ethanol, then dried and weighed.

\subsection{Characterization of $\mathrm{Cu}$ Nanoparticles}

The $\mathrm{Cu}$ nanoparticles used in this work were acquired from Sky Spring Nanomaterials Inc. (Houston, TX, USA), and had a spherical morphology, 99.8\% purity and an average diameter of $25 \mathrm{~nm}$. The morphology of $\mathrm{nCu}$ was determined using a scanning electronic microscope (SEM) (JEOL-JMS-7401F) and Titan transmission microscope (TEM) (Model: JSM-7410). Also, Energy dispersive X-ray (EDX) analysis was done using Siemens EDX system, D5000 model.

\subsection{Absorption of $\mathrm{Cu}$ Nanoparticles in Cs-PVA Hydrogels}

To absorption of $\mathrm{Cu}$ nanoparticles in hydrogels first, $100 \mathrm{mg}$ of the $\mathrm{nCu}$ were dispersed in a $1 \%$ Tween solution by ultrasound for $5 \mathrm{~min}$ ( 50 Watt power and 70\% frequency), and then dilutions were 
prepared to obtain concentrations of $10,2,0.2$, and $0.02 \mathrm{mg}$, which were subsequently absorbed each in $1 \mathrm{gram}$ of Cs-PVA hydrogel and dried at a temperature of $60^{\circ} \mathrm{C}$.

\subsection{Experimental Development}

Jalapeño pepper plants (Capsicum annuum L.) hybrid var. Grande were established in a multi-tunnel greenhouse with a polyethylene cover at the Department of Horticulture of the Autonomous Agrarian University Antonio Narro and developed for 120 days after transplant (dat). The average temperature was $22.4^{\circ} \mathrm{C}$, while the active photosynthetic radiation was on average $677 \mu \mathrm{mol} \mathrm{m}{ }^{-2} \mathrm{~s}^{-1}$ and the average relative humidity was $62 \%$. Planting density was three plants per square meter. The substrate used was a mixture of peat moss and perlite (50:50, $v / v)$, placed in black $12 \mathrm{~L}$ polyethylene bags. Before transplantation, $0.33 \mathrm{~g}$ of the solid Cs-PVA hydrogels were weighed for application of the treatments and distributed in the substrate in the lower, middle, and upper part of the pot, to cover a larger portion of the pot until $1 \mathrm{~g}$ of the hydrogel was added to each pot. A drip irrigation system was used to apply five irrigations per day, with an approximate application of $1.5 \mathrm{~L}$ per plant per day using a Steiner solution [35], with varying concentrations. The nutrient solution was applied to $25 \%$ during the vegetative growth of the crop, 50\% during flowering and $75 \%$ during the development of the fruit [10]. The nutrient solution was maintained at $\mathrm{pH}$ 6.5. This nutrient solution $(75 \%)$ contained $2.4 \mathrm{mg} \mathrm{L}^{-1}$ of $\mathrm{Cu}$ in a chelated form (EDTA). The treatments used were as follows: an absolute control, Cs-PVA, and four treatments with $0.02,0.2,2$, and $10 \mathrm{mg}(\mathrm{nCu}) \mathrm{g}^{-1}$ (Cs-PVA). These treatments were applied one time only prior to transplantation considering one gram of hydrogels per plant, resulting in a total of $0.02,0.2,2$, and $10 \mathrm{mg}$ of $\mathrm{nCu}$ per plant, respectively.

\subsection{Variables for Growth and Production of Jalapeño Pepper}

The number of fruits harvested per plant, the average weight of fruits (g), the total weight of harvested fruits and the fresh weight of aerial biomass (g) were registered to evaluate the growth and yield of the jalapeño pepper plants at the end of the crop. Dry weight of aerial biomass $(\mathrm{g})$ was obtained after drying in a DHG9240A drying oven for $72 \mathrm{~h}$ at a constant temperature of $80^{\circ} \mathrm{C}$.

\subsection{Storage of Jalapeño Pepper Fruits}

The fruits were harvested at 90 days after planting and were selected for uniform color and to verify that they did not present physical and pathological damage. Once harvested, the fruits were divided into lots of 50 fruits per treatment; each fruit constituted an experimental unit. To evaluate the effect of $\mathrm{nCu}$ on post-harvest quality and behavior, jalapeño pepper fruits were stored at room temperature $\left(20 \pm 1{ }^{\circ} \mathrm{C}\right)$ and in cold storage conditions $\left(10 \pm 1^{\circ} \mathrm{C}\right.$ and $80 \%$ relative humidity), and three storage times $(0,15$, and 30 days) were evaluated. There were six repetitions for fresh weight loss and three repetitions for physicochemical and functional analysis.

\subsection{Physicochemical Analysis}

The weight changes experienced by the fruits during the storage period were measured using a digital scale (OHAUS). Weight loss was reported as a percentage of accumulated losses with respect to the initial weight of the fruit.

For determination of the physicochemical variables, the fruits were cut into slices and ground in a knife mill (RTSCH GM 200, Haan, Germany). Total soluble solids ( ${ }^{\circ}$ Brix) were determined using a digital refractometer (PR-101, ATAGO PALETTE, Tokyo, Japan). The $\mathrm{pH}$ was measured using a digital potentiometer (Hanna Instruments, Woonsocket, RI, USA) and titratable acidity was determined using the AOAC method (942.15) based on titration of the sample with $0.1 \mathrm{M} \mathrm{NaOH}$ to $\mathrm{pH}$ 8.2 using phenolphthalein as an indicator [36]; titratable acidity was reported in \% of citric acid on fresh weight. 


\subsection{Functional Analysis}

The capsaicin content in fruits was determined by the method of Bennett and Kirby [37]. The ripe fruits were lyophilized and macerated in mortar. One gram of the sample was weighed, $10 \mathrm{~mL}$ of absolute ethanol was added and the mixture was stirred for $15 \mathrm{~min}$. It was filtered on Whatman No. 1 and was gauged at $25 \mathrm{~mL}$ ethanol. The sample was transferred to a separatory funnel and $2.5 \mathrm{~mL}$ of buffer at $\mathrm{pH}$ 2.8, $0.5 \mathrm{~mL}$ of ethanol, $20.5 \mathrm{~mL}$ distilled water, and $10 \mathrm{~mL}$ of adogen-toluene solution were added. The mixture was vigorously stirred for $1 \mathrm{~min}$. Subsequently, the absorbance of capsaicin was determined in the organic phase in a spectrophotometer (Varian CARY 100BIO, Turin, Italy) at a wavelength of $286 \mathrm{~nm}$. To determine the capsaicin content in the samples, a calibration curve was constructed with this antioxidant (Sigma, Co, Kawasaki, Japan) in a range of 0 to $0.40 \mathrm{mg} \mathrm{mL}^{-1}$, dissolved in the solvents mentioned.

To prepare samples for the next functional analyses, the fruits were sliced and stored in an ultra-freezer at $-70^{\circ} \mathrm{C}$ (3003 Ultrafreezer Thermo Scientific, Waltham, MA, USA) for one week and lyophilized at $133 \times 10^{-3}$ mbar (Labconco, FreeZone 6, Kansas City, MO, USA). Once lyophilized, the samples were ground in a knife mill (RTSCH GM 200, Haan, Germany) at 9000 rpm for 50 s until a fine powder of $150 \mu \mathrm{m}$ diameter particles was obtained.

For the determination of the antioxidant activity of the ABTS $\left[2,2^{\prime}\right.$-azino-bis (3-ethylbenzothiazolin-6-sulfonic acid)] radical, the technique described in $\operatorname{Re}$ et al. [38] was employed, based on the discoloration of the radical ABTS cation. For sample preparation, $1 \mathrm{~g}$ of lyophilized powder was weighed and $20 \mathrm{~mL}$ of distilled water was added and centrifuged at $17,500 \mathrm{rpm}$ for $10 \mathrm{~min}$. Then, $1 \mathrm{~mL}$ of the supernatant was diluted in $20 \mathrm{~mL}$ of $80 \%$ methyl alcohol. The ABTS radical $(7 \mu \mathrm{M})$ was reacted with potassium persulfate (Mallinckrodt Chemicals, St. Louis, MO, USA, $2.45 \mu \mathrm{M}$ ); the reagents were mixed in a ratio of 1:1. This mixture was left to stand, then covered for $16 \mathrm{~h}$ before starting the tests. Once the ABTS radical formed, it was diluted with $20 \%$ ethanol until it reached an absorbance of $0.7 \pm 0.01$ at $734 \mathrm{~nm}$. The initial absorbance in the spectrophotometer (Varian CARY 100BIO, Turin, Italy) was measured in a quartz cell; then, $100 \mu \mathrm{L}$ of pepper sample was added and stirred rapidly, and the change in absorbance 6 min into the reaction was recorded. Antioxidant activity was determined using a standard curve with ascorbic acid (95-125 mg AAE L ${ }^{-1}$ ). The results were expressed in milligrams of ascorbic acid equivalents per $100 \mathrm{~g}$ of dry weight (mg AAE $100 \mathrm{~g}^{-1} \mathrm{DW}$ ).

To determine the antioxidant activity of the DPPH (2,2-diphenyl-1-picrylhydrazyl) radical, $1 \mathrm{~g}$ of lyophilized powder was weighed to prepare the sample and $20 \mathrm{~mL}$ of distilled water was added and centrifuged at 17,500 rpm for $10 \mathrm{~min}$. Next, $1 \mathrm{~mL}$ of the supernatant was diluted in $20 \mathrm{~mL}$ of $80 \%$ methyl alcohol. Then, $2.5 \mathrm{~mL}$ of the DPPH (Sigma Aldrich, St. Louis, MO, USA) radical of a DPPH $6.1 \times 10^{-5} \mathrm{M}$ methanolic solution was placed in a quartz cell and reacted with $0.5 \mathrm{~mL}$ of the pepper sample. The mixture was allowed to stand in the dark for $30 \mathrm{~min}$, and the change in absorbance was recorded at $517 \mathrm{~nm}$ in a spectrophotometer (Varian CARY 100BIO, Turin, Italy). The antioxidant activity was determined using a standard curve with ascorbic acid $\left(0-80 \mathrm{mg} \mathrm{L}^{-1}\right)$. The results were expressed as mg AAE $100 \mathrm{~g}^{-1}$ DW [39].

The determination of total phenols was carried out using the Folin-Ciocalteu methodology [40]. Briefly, $1 \mathrm{~g}$ of lyophilized pepper was weighed and hydrated with $20 \mathrm{~mL}$ of distilled water until a homogeneous mixture was obtained, and the suspension was then centrifuged at $17,500 \mathrm{rpm}$ and decanted. Next, $0.5 \mathrm{~mL}$ of the supernatant was added to three test tubes, mixed with $2.5 \mathrm{~mL}$ of the diluted 0.2 N Folin-Ciocalteu reagent (1:10) (Sigma Aldrich, St. Louis, MO, USA) and allowed to stand for $5 \mathrm{~min}$. Subsequently, $2 \mathrm{~mL}$ of a $7.5 \%$ sodium carbonate solution was added until a homogeneous mixture was achieved. This mixture was allowed to stand for $2 \mathrm{~h}$, and the absorbance of the mixture was then read in a spectrophotometer (Varian CARY 100BIO, Turin, Italy) with quartz cells at a wavelength of $760 \mathrm{~nm}$. The results obtained were expressed in milligrams of gallic acid equivalents per $100 \mathrm{~g}$ of dry weight (mg GAE $100 \mathrm{~g}^{-1} \mathrm{DW}$ ), according to the calibration curve for gallic acid and concentrations of 20-80 $\mathrm{mg} \mathrm{L}^{-1}$. 
The total flavonoid content was determined using the Dowd method, adapted by Arvouet-Grand et al. [41]. A solution of $2 \%$ aluminum trichloride $\left(\mathrm{AlCl}_{3}\right)$ (Fermont, Monterrey, Mexico) in methanol was used. First, $0.1 \mathrm{~g}$ of lyophilized pepper was weighed and suspended in $10 \mathrm{~mL}$ of methanol, then homogenized and filtered through paper (Whatman No. 1). Next, $2 \mathrm{~mL}$ of the filtered sample plus $2 \mathrm{~mL}$ of the $\mathrm{AlCl}_{3}$ methanolic solution was allowed to stand for $20 \mathrm{~min}$ in the dark. Subsequently, the assay was placed in a quartz cell, and the absorbance was recorded at a wavelength of $415 \mathrm{~nm}$ in a spectrophotometer (Varian CARY 100BIO, Turin, Italy). The total flavonoid content was determined using a calibration curve with quercetin for concentrations of $200-400 \mathrm{mg} \mathrm{L}^{-1}$. The results were expressed in milligrams equivalent of quercetin per $100 \mathrm{~g}$ of dry weight (mg EQ $100 \mathrm{~g}^{-1} \mathrm{DW}$ ).

\subsection{Statistical Analysis}

The crop was established using an experimental design of a Latin square $(6 \times 6)$ with 18 experimental units per treatment for growth and yield variables. A completely random design was used for the variables of physicochemical and functional analysis, with six and three experimental units respectively per treatment; only capsaicin has five experimental units. Statistical analysis of each variable was performed using the statistical program InfoStat (2016), in which an analysis of variance and a comparison of Fisher Least Significant Difference means $(p \leq 0.05)$ were performed.

\section{Conclusions}

The application of Cu nanoparticles in hydrogels of chitosan-PVA affected plant growth, especially at high concentrations, but increased the number and average weight of fruits. This indicates that the application of $\mathrm{nCu}$ generates both positive and negative effects on the growth and development of the jalapeño pepper crop, depending on the dose applied. Chitosan-PVA had no effect on jalapeño pepper plant.

The $\mathrm{Cu}$ nanoparticles in hydrogels of chitosan-PVA also minimized the weight loss of fruits stored for 30 days under both refrigeration and room temperature; they also increase the amount of total soluble solids in fruits stored at room temperature for 15 days. Cs-PVA shows more fruit weight loss at 15 days under refrigeration than the control, and had no effect to other conditions.

The application of $\mathrm{Cu}$ nanoparticles in hydrogels of chitosan-PVA increases the capsaicin content on pepper fruits. However, Cs-PVA alone had no effect on this variable.

In general, application of $\mathrm{Cu}$ nanoparticles in hydrogels of chitosan-PVA increased the content of antioxidants ABTS and DPPH, and the total phenols and flavonoids $(4 \%, 6.6 \%, 5.9 \%$, and $12.71 \%$, respectively) in jalapeño pepper fruits stored for 15 days at room temperature. Refrigeration increased DPPH antioxidants, total phenols and flavonoids (23.9\%, $1.54 \%$, and $17.2 \%$, respectively). Cs-PVA had no effect on these variables at room temperature. However, Cs-PVA decreases antioxidants ABTS and the total phenols under refrigeration (14.3 and 48.7, respectively); and the other hand antioxidants DPPH and flavonoids increase under this condition ( $9.7 \%$ and $2.6 \%$, respectively).

The application of $\mathrm{Cu}$ nanoparticles in hydrogels of chitosan-PVA, even when applied to the substrate, not only had an effect on the development of the jalapeño pepper crop but also modified the post-harvest characteristics of jalapeño pepper fruits.

Acknowledgments: UAAAN Proyecto interno 38111- 425104001-2230: “Nanopartículas de cobre en hidrogeles de Quitosán-PVA para la inducción de capacidad antioxidante, tolerancia a estrés abiótico y expresión génica en solanáceas". CIQA Proyecto interno FD-0010: “Optimización de la absorción de nanopartículas de cobre (ncu) en hidrogeles de quitosán y su actividad antimicrobiana".

Author Contributions: Juárez-Maldonado and Benavides-Mendoza conceived and designed the experiments; Hernández-Fuentes performed the analysis of laboratory; Ortega-Ortiz and Cadenas-Pliego contributed reagents and materials; Pinedo-Guerrero performed the field experiments. All authors were responsible for processing information and manuscript writing. All authors read and approved the final manuscript.

Conflicts of Interest: The authors declare no conflict of interest. 


\section{References}

1. SAGARPA. Producción nacional de chile alcanza 2.3 millones de toneladas [National production of peppers reaches 2.3 million tons]. 2017. Available online: http://www.sagarpa.gob.mx/Delegaciones/nayarit/ boletines/Paginas/BNSAGENE052017.aspx (accessed on 15 April 2017).

2. SIAP. Un panorama del cultivo del chile [An overview of the cultivation of chili pepper]. 2015. Available online: www.gob.mx/siap (accessed on 13 December 2016).

3. Sweat, K.G.; Broatch, J.; Borror, C.; Hagan, K; Cahill, T.M. Variability in capsaicinoid content and Scoville heat ratings of commercially grown Jalapeño, Habanero and Bhut Jolokia peppers. Food Chem. 2016, 210, 606-612. [CrossRef] [PubMed]

4. Barbero, G.F.; Liazid, A.; Azaroual, L.; Palma, M.; Barroso, C.J. Capsaicinoid contents in peppers and pepper-related spicy foods. Int. J. Food Prop. 2016, 19, 485-493. [CrossRef]

5. Ornelas-Paz, J.; Martinez-Burrola, J.M.; Ruiz-Cruz, S.; Santana-Rodriguez, V.; Ibarra-Junquera, V.; Olivas, H.I. Effect of cooking on capsaicinoids and phenolics contents of mexican peppers. Food Chem. 2010, 119, 1619-1625. [CrossRef]

6. Lili, H.; Liu, Y.; Mustapha, A.; Lin, M. Antifungal activity of zinc oxide nanoparticles against Botrytis cinerea and Penicillium Expansum. Microbiol. Res. 2011, 166, 207-215.

7. Wang, P.; Lombi, E.; Zhao, F.; Kopittke, P.M. Nanotechnology: A new opportunity in plant sciences. Trends Plant Sci. 2016, 21, 699-712. [CrossRef] [PubMed]

8. Rizwan, M.; Ali, S.; Farooq, Q.M.; Sik, O.Y.; Adrees, M.; Ibrahim, M.; Zia-ur-Rehman, M.; Farid, M.; Abbas, F. Effect of metal and metal oxide nanoparticles on growth and physiology of globally important food crops: A critical review. J. Hazard. Mater. 2017, 322, 2-16. [CrossRef] [PubMed]

9. Fu, P.P.; Xia, O.; Hwang, H.M.; Ray, P.C.; Yu, H. Mechanisms of nanotoxicity: Generation of reactive oxygen species. J. Food Drug Anal. 2014, 22, 64-75. [CrossRef] [PubMed]

10. Juárez-Maldonado, A.; Ortega-Ortiz, H.; Pérez-Labrada, F.; Cadenas-Pliego, G.; Benavidez-Mendoza, A. $\mathrm{Cu}$ nanoparticle absorbed on chitosan hydrogels positively alter morphological production and quality characteristics of tomato. J. Appl. Bot. Food Qual. 2016, 89, 183-189.

11. White, P.J.; Brown, P.H. Plant nutrition for sustainable development and global health. Ann. Bot. 2010, 105, 1073-1080. [CrossRef] [PubMed]

12. Kamari, A.; Pulford, I.D.; Hargreaves, J.S. Chitosan as a potential amendment to remediate metal contaminated soil-A characterisation study. Colloids Surf. B 2011, 82, 71-80. [CrossRef] [PubMed]

13. Zuverza-Mena, N.; Medina-Veto, I.A.; Barrios, A.C.; Wenjuan, T.; Peralta-Virea, J.R.; Garcia-Torresdey, J.L. Copper nanoparticles/compounds impact agronomic and physiological parameters in cilantro (Coriandrum sativum). Environ. Sci. Process. Impacts 2015, 17, 1783-1793. [CrossRef] [PubMed]

14. Stampoulis, D.; Sinha, S.K.; White, J.C. Assay-dependent phytotoxicity of nanoparticles to plants. Environ. Sci. Technol. 2009, 43, 9473-9479. [CrossRef] [PubMed]

15. Dimkpa, C.O.; McLean, J.E.; Latta, D.E.; Manangón, E.; Britt, D.W.; Jonhson, W.P.; Boyanov, M.I.; Anderson, A.J. $\mathrm{CuO}$ and $\mathrm{ZnO}$ nanoparticles: Phytotoxicity, metal speciation, and induction of oxidative stress in sand-grown wheat. J. Nanopart Res. 2012, 14, 1125-1129. [CrossRef]

16. Chatterjee, N.; Eom, H.J.; Choi, J. A systems toxicology approach to the surface functionality control of graphene-cell interactions. Biomaterials 2014, 35, 1109-1127. [CrossRef] [PubMed]

17. Van-Aken, B. Gene expression changes in plants and microorganisms exposed to nanomaterials. Curr. Opin. Biotechnol. 2015, 33, 206-219. [CrossRef] [PubMed]

18. Benavides-Mendoza, A.; Romero-García, J.; Ledesma-Pérez, A.S.; Raygoza-Castro, J.M. La aplicación foliar de quitosano en ácido acético aumenta la biomasa de la lechuga. Biotam Nueva Ser. 2001, 12, 1-6.

19. Pérez-de-Luque, A. Interaction of Nanomaterials with Plants: What Do We Need for Real Applications in Agriculture? Front. Environ. Sci. 2017, 5, 1-7. [CrossRef]

20. Nair, P.M.G.; Chung, I.M. Study on the correlation between copper oxide nanoparticles induced growth suppression and enhanced lignification in Indian mustard (Brassica juncea L.). Ecotoxicol. Environ. Saf. 2015, 113, 302-313. [CrossRef] [PubMed]

21. Nair, P.M.G.; Chung, I.M. A Mechanistic Study on the Toxic Effect of Copper Oxide Nanoparticles in Soybean (Glycine max L.) Root Development and Lignification of Root Cells. Biological. Trace Elem. Res. 2014, 162, 342-352. [CrossRef] [PubMed] 
22. Nair, P.M.G.; Chung, I.M. Impact of copper oxide nanoparticles exposure on Arabidopsis thaliana growth, root system development, root lignificaion, and molecular level changes. Environ. Sci. Pollut. Res. 2014, 21, 12709-12722. [CrossRef] [PubMed]

23. Hernández-Fuentes, A.D.; Campos-Montiel, R.; Pinedo-Espinoza, J.M. Postharvest behavior of bell pepper (Capsicum annum L.) variety california by the effect of chemical fertilization and appliance of lombrihumus. Rev. Iberoamer. Tecnol. Postcosecha 2010, 11, 82-91.

24. Báez-Sañudo, M.; Siller-Cepeda, J.; Rangel, D.; Contreras-Martínez, R.; Contreras-Angulo, L. Dehydration and loss of firmness in colored chili peppers stored under market simulation. In Proceedings of the Second World Pepper Convention, Centro de Investigación en Alimentación y Desarrollo, Sinaloa, Mexico, 2005.

25. Espinosa-Torres, L.E.; Pérez-Grajales, M.; Martínez-Damián, M.T.; Castro-Brindis, R.; Barrios-Puente, G. Effect of packaging and postharvest storage temperatures on manzano hot peppers (Capsicum pubescens Ruíz \& Pavón). Rev. Chapingo Ser. Hortic. 2010, 16, 115-121.

26. Ghasemnezhad, M.; Sherafati, M.; Payvast, G.A. Variation in phenolic compounds, ascorbic acid and antioxidant activity of five coloured bell pepper (Capsicum annum) fruits at two different harvest times. J. Funct. Foods 2011, 3, 44-49. [CrossRef]

27. Wills, R.; McGlasson, B..; Graham, D.; Jo, D. Postharvest: An Introduction to the Physiology $\mathcal{E}$ Handling of Fruit, Vegetable and Ornamentals, 4th ed.; CAB International: Oxfordshire, UK, 1998; p. 262.

28. Tucker, G.A. Biochemistry of Fruit Ripening; Editorial Chapman and Hall: Boca Raton, FL, USA, 1993; pp. 1-15.

29. Shobha, G.; Moses, V.; Ananda., S. Biological synthesis of copper nanoparticle and its impact-A review. Int. J. Farmaceut. Sci. Invent. 2014, 3, 28-38.

30. Kim, S.; Lee, K.W.; Park, J.; Lee, H.J.; Hwang, I.K. Effect of drying in antioxidant activity and changes of ascorbic acid and color by different drying and storage in Korean red pepper (Capsicum annuum L.). Int. J. Food Sci. Technol. 2006, 41, 90-95. [CrossRef]

31. Vega-Gálvez, A.; Di, K.; Rodríguez, K.; Lemus-mondaca, R.; Miranda, M.; Pérez-Won, M. Effect of air-drying temperature on physico-chemical properties, antioxidant capacity, colour and total phenolic content of red pepper. Food Chem. 2009, 117, 647-653. [CrossRef]

32. Deepa, N.; Kaur, C.; George, B.; Singh, B.; Kapoor, H.C. Antioxidant constituents in some sweet pepper (Capsicum annuum L.) genotypes during maturity. Lebensm. Wiss. Technol. 2007, 40, 121-129. [CrossRef]

33. Lee, Y.; Howard, L.R.; Villalon, B. Flavonoids and Antioxidant Activity of Fresh Pepper (Capsicum annuum) Cultivars. J. Food Sci. 1995, 60, 473-476. [CrossRef]

34. Howard, L.R.; Talcott, S.T.; Brenes, C.H.; Villalon, B. Changes in phytochemical and antioxidant activity of selected pepper cultivars (Capsicum species) as influenced by maturity. J. Agric. Food Chem. 2000, 48, 1713-1720. [CrossRef] [PubMed]

35. Steiner, A.A. A universal method for preparing nutrient solutions of a certain desired composition. Plant Soil 1961, 15, 134-154. [CrossRef]

36. AOAC. Vitamin and other nutrient. In Official Methods of Analysis of the Association of Official Analytical Chemists International, 17th ed.; Hoerwitz, W., Ed.; AOAC International: Gaithersburg, MD, USA, 2000.

37. Bennett, D.J.; Kirby, G.W. Constitution and biosynthesis of capsaicin. J. Chem. Soc. C 1968, 442-446. [CrossRef]

38. Re, R.; Pellegrini, N.; Proteggente, A.; Pannala, A.; Yanga, M.; Rice-Evans, C.A. Antioxidant activity applying an improved ABTS radical catión decolorization assay. Free Rad. Biol. Med. 1999, 26, 1231-1237. [CrossRef]

39. Brand-Williams, W.; Cuvelier, M.E.; Berset, C. Use of free radical method to evaluate antioxidant activity. LWT-Food Sci. Technol. 1995, 28, 25-30. [CrossRef]

40. Singleton, V.L.; Orthfer, R.; Lamuela-Raventos, R.M. Analysis of total phenols and other oxidation substrates and antioxidants by means means of the Folín-Ciocalteu reagent. Methods Enzymol. 1999, 299, 152-178.

41. Arvouet-Grand, A.; Vennat, B.; Pourrat, A.; Legret, P. Standardization of a propolis extract and identification of the main constituents. J. Pharm. Belg. 1994, 49, 462-468. [PubMed]

Sample Availability: Samples of the compounds are not available from the authors.

(C) 2017 by the authors. Licensee MDPI, Basel, Switzerland. This article is an open access article distributed under the terms and conditions of the Creative Commons Attribution (CC BY) license (http://creativecommons.org/licenses/by/4.0/). 